\title{
Rapid Identification of Acacia Species With Potential Salt Tolerance by Using Nuclear Ribosomal DNA Markers
}

\author{
Shanthi Joseph ${ }^{1}$, Mrinal Bhave ${ }^{1}$, Joseph T. Miller ${ }^{2} \&$ Daniel J. Murphy ${ }^{3}$ \\ ${ }^{1}$ Environment and Biotechnology Centre, Faculty of Life and Social Sciences, Swinburne University of \\ Technology, P.O. Box 218, John St, Hawthorn, Victoria, 3122, Australia \\ ${ }^{2}$ Centre for Australian National Biodiversity Research, CSIRO Plant Industry, GPO Box 1600, Canberra, ACT \\ 2601, Australia \\ ${ }^{3}$ Royal Botanic Gardens Melbourne, Private Bag 2000, Birdwood Avenue, South Yarra, Victoria, 3141, \\ Australia \\ Correspondence: Mrinal Bhave, Environment and Biotechnology Centre, Faculty of Life and Social Sciences, \\ Swinburne University of Technology, P.O. Box 218, John St, Hawthorn, Victoria, 3122, Australia. Tel: \\ 61-392-145-759. E-mail: mbhave@swin.edu.au
}

Received: July 8, 2013 Accepted: August 13, 2013 Online Published: August 23, 2013

doi:10.5539/sar.v2n4p77

URL: http://dx.doi.org/10.5539/sar.v2n4p77

\begin{abstract}
Use of saline lands for agroforestry relies primarily on plant species that have the trait of salinity tolerance, and also other economic and agronomic benefits. The selection of species, however, also needs to consider other key factors such as compatibility with existing flora, and potential for environmental benefits such as improved soil fertility or lowering of the water table in the case of dryland salinity. The testing of candidate species in particular environments needs substantial investments of costs and time. In this paper, a novel approach is presented for the rapid identification of potentially salt tolerant Acacia species, based on molecular phylogenetic analysis. The approach has been applied to four species groups, Acacia pendula, A. salicina, A. victoriae and A. stenophylla. The nuclear-encoded ribosomal DNA internal and external transcribed spacer (ITS and ETS) regions were used as markers, and phylogenetic analyses undertaken to identify closely related species that may share the salt tolerance traits. Such a methodology could be used to more rapidly identify candidate native species for agroforestry in salinity-affected regions and for preventing further expansion of salinity, thus assisting in biodiversity conservation.
\end{abstract}

Keywords: Acacia, phylogeny, ribosomal RNA, ITS, ETS, salinity

Abbreviations: ETS: External Transcribed Spacer; IGS: Inter-Genic Spacer; ITS: Internal Transcribed Spacer; LSU: Large Sub-Unit; SSU: Small Sub-Unit.

\section{Introduction}

The environmental challenge of dryland salinity currently affects approximately 3.3 million hectares of arable lands in Australia, and could further expand to 5.7 million hectares if left unchecked (Department of Sustainability, Environment, Water, Population and Communities; http://www.environment.gov.au/land/pressures/salinity/). The negative impact of salinity has prompted serious action by the Australian government to implement programs such as the National Action Plan for Salinity and Water Quality (Pannell \& Roberts, 2010). The Australian landscape has vast reserves of salt beneath the land surface. Species of perennial Australian native vegetation are well-adapted to these harsh conditions, utilizing available water, also maintaining the water table and immobilizing the salt. However, dramatic changes in land use since the European settlement have led to replacement of the deep-rooted native perennials with shallow-rooted cereal crops and pastures. This has resulted in mobilization of salt to the soil surface, causing toxicity to plants and significant loss of crop land and native vegetation. One of the key strategies for reclamation of salinity-degraded lands is revegetation with well-adapted native species, some of which maybe additionally useful as sources of food, fodder, fuel, fiber, resins, essential oils or pharmaceutical products (Maslin \& McDonald, 2004).

The genus Acacia (wattle), first described in 1754 by Philip Miller, belongs to the tribe Acacieae and is the 
largest genus within the legume subfamily Mimosoideae (Murphy, 2008). The name Acacia is now restricted to the subgenus formerly known as Phyllodineae (synonym Racosperma), confining it mainly to Australia (Maslin, 2006), where it is the largest genus of vascular plants and widespread in dry and semi-arid regions. Acacia species thrive in a diverse range of environments and many species tolerate high salinity, sodicity, high $\mathrm{pH}$ and waterlogged soils (Niknam \& McComb, 2000). Additionally, several salt-tolerant acacias, such as A. saligna, A. stenophylla, A. salicina and A. ampliceps, have the potential to provide forage and fodder (Vercoe, 1987). Acacia species harbor nitrogen-fixing rhizobia that can improve soil fertility (Hoque, Broadhurst, \& Thrall, 2011) and are in use for reclamation of severely degraded lands in Brazil (Chaer, Resende, Campello, De Faria, \& Boddey, 2011). Some species provide timber and edible fruit and seeds. However, despite the benefits, Acacia species are currently under-investigated and underutilized, and information on salinity tolerant species with agroforestry potential is especially limited. Four species (A. pendula, A. salicina, A. stenophylla, A. victoriae), were found to be salt tolerant (among other vegetation) in a unique project on reclamation of saline lands in Victoria (Australia), [Phil Dyson and Ian Rankin, Northern United Forestry Group (NUFG) Bendigo, Australia; personal communications 2009] areas of which show high surface soil salinity [12-14 deci-Siemens/metre (dS/m)] and sub-soil salinity (4 dS/m) (NUFG Kamarooka Project; http://www.nufg.org.au/Kamarooka\%20Project.htm). This study aims to use molecular phylogenetics to rapidly identify the close relatives of these species in order to exploit their potential for agroforestry on saline lands.

Nuclear ribosomal DNA (rDNA) markers such as the internal transcribed spacer (ITS) and the external transcribed spacer (ETS) (Baldwin \& Markos, 1998; Mort et al., 2007) and chloroplast loci (e.g. atpF-H, matK, $p s b K-I, r b c L, r p o B, r p o C l$ and trnH-psbA) (Dong, Liu, Yu, Wang, \& Zhou, 2012) have been commonly used in plant molecular systematics. The ITS1 and ITS2 regions of plant rRNA genes are used most frequently to study phylogeny at genus and species levels due to advantages such as high sequence variability, copy numbers and ease of amplification (Kay, Whittall, \& Hodges, 2006; Mort et al., 2007). ITS is adjacent to the conserved 5.8S rRNA gene region and is flanked by the conserved $18 \mathrm{~S}$ and $26 \mathrm{~S}$ rRNA genes, and this entire region is tandemly repeated thousands of times to make up the rDNA. The ETS of 18S-26S rDNA belongs to the same transcriptional unit. It may have evolved under similar functional constraints and complements the ITS data to yield more characters for significant phylogenetic inferences in angiosperms (Baldwin \& Markos, 1998). The ITS and ETS are currently the most commonly sequenced loci for Acacia and provide the best available comparative dataset.

Comparative biology is based on the expectation that closely related organisms share traits, such as salinity tolerance, that are less common in more distantly related organisms (Cracraft, 2002). Therefore, clarifying molecular phylogenetic relationships can aid in selecting candidate species for a particular trait. Miller, Murphy, Brown, Richardson, and González-Orozco (2011) used plastid and nuclear rDNA data to test for invasiveness of species across a broad framework of 110 acacias. Although the invasive species did not form a monophyletic group, some evidence for phylogenetic grouping of invasive species was found. The study also identified sister species of the known invasive species that may have increased potential for invasiveness. The present study takes a similar approach, to rapidly identify sister species of known salt tolerant taxa. ITS and ETS sequence data were obtained for species in morphological groups closely related to the four salt-tolerant species, $A$. pendula, A. salicina, A. stenophylla and A. victoriae, mentioned above. These data, combined with an extensive Acacia dataset of ITS and ETS markers, was used to generate phylogenetic relationships and identify further species with a potential for salt tolerance.

\section{Materials and Methods}

\subsection{Plant Tissue Sampling for Genomic DNA Extraction}

The thirty species to be analysed were initially selected based on species groups morphologically related to the salt tolerant species described above (A. pendula, A. salicina, A. stenophylla and A. victoriae), as described in Flora of Australia (Orchard \& Wilson, 2001a; b). The phyllode or leaf tissue (20mg) was removed from the herbarium sheets held at Royal Botanic Gardens, Melbourne (herbarium voucher numbers given in Table 1) and used for genomic DNA extraction using the DNeasy Plant Mini Kit (Qiagen Australia). A dataset of ITS and ETS sequences was constructed using data from Brown, Murphy, Kidman, and Ladiges (2012). Paraserianthes lophantha (voucher MEL2057862; GenBank accessions: ITS: EF638203; ETS: EF638105.1) was used as the out-group, based on Brown, Murphy, Miller, and Ladiges (2008) who concluded that it is sister to Acacia. 
Table 1. Identification of species morphologically related to A. stenophylla, A. salicina, A. pendula and A. victoriae

\begin{tabular}{|c|c|c|c|}
\hline $\begin{array}{l}\text { Morphologically related } \\
\text { species }\end{array}$ & Key indicator(s) of plausible relationship & References & $\begin{array}{l}\text { Voucher } \\
\text { number }\end{array}$ \\
\hline \multicolumn{3}{|c|}{ Species of interest: $A$. stenophylla } & MEL 2312528 \\
\hline A. coriacea & $\begin{array}{l}\text { Long phyllodes and growth habit resembling } A \text {. } \\
\text { stenophylla. }\end{array}$ & 2 & MEL 2313071 \\
\hline A. sibilans & Closely related to $A$. coriacea in phyllode morphology. & 2 & MEL2327552 \\
\hline A. calcicola & A. coriacea sometimes confused with $A$. calcicola. & 2 & MEL 2233895 \\
\hline \multicolumn{3}{|c|}{ Species of interest: $A$. salicina } & MEL 2286869 \\
\hline A. bivenosa & A. salicina belongs to the $A$. bivenosa group. & 3 & MEL 2306646 \\
\hline A. ligulata & $\begin{array}{l}\text { A. salicina was often confused with } A \text {. ligulata and } A \text {. } \\
\text { ampliceps. }\end{array}$ & 1,3 & MEL 2326226 \\
\hline A. ampilceps & $\begin{array}{l}\text { A. salicina was often confused with } A \text {. ligulata and } A \text {. } \\
\text { ampliceps. }\end{array}$ & 1,3 & MEL 2306643 \\
\hline A. cupularis & Belongs to the $A$. bivenosa group. & 3 & MEL 2278496 \\
\hline A. didyma & Belongs to the $A$. bivenosa group. & 3 & MEL 2283488 \\
\hline A. rostellifera & Belongs to the $A$. bivenosa group. & 3 & MEL 2319042 \\
\hline A. sclerosperma & Belongs to the $A$. bivenosa group. & 3 & MEL 2042807 \\
\hline A. startii & Belongs to the $A$. bivenosa group. & 3 & MEL 2297013 \\
\hline A. telmica & Belongs to the $A$. bivenosa group. & 3 & MEL 710783 \\
\hline A. tysonii & Belongs to the $A$. bivenosa group. & 3 & MEL 2137099 \\
\hline A. xanthina & Belongs to the $A$. bivenosa group. & 3 & MEL 2327555 \\
\hline \multicolumn{3}{|c|}{ Species of interest: $A$. pendula } & MEL 2233883 \\
\hline A. omalophylla & A. pendula closely related to $A$. omalophylla. & 2 & MEL 2328341 \\
\hline A. melvillei* & $\begin{array}{l}\text { Very closely related to } A \text {. omalophylla, and in } \\
\text { Queensland, both are known as Yarran. }\end{array}$ & 2 & MEL 2034608 \\
\hline \multicolumn{3}{|c|}{ Species of interest: $A$. victoriae* } & $\begin{array}{l}\text { MELU SRA } \\
260\end{array}$ \\
\hline A. alexandri* & $\begin{array}{l}\text { A. victoriae with long and linear phyllodes may be } \\
\text { confused with } A \text {. alexandri. }\end{array}$ & 2,4 & $\begin{array}{ll}\text { MELU } & \text { SRA } \\
148 & \end{array}$ \\
\hline A. aphanoclada* & Belongs to the $A$. victoriae group. & 2,4 & $\begin{array}{l}\text { MELU SRA } \\
224\end{array}$ \\
\hline A. chartacea & Belongs to the $A$. victoriae group. & 2,4 & MEL 721448 \\
\hline A. cuspidifolia* & Belongs to the $A$. victoriae group. & 2,4 & MEL SRA 115 \\
\hline A. dempsteri* & Belongs to the $A$. victoriae group. & 2,4 & MEL 2096892 \\
\hline A. pickardii & Belongs to the $A$. victoriae group. & 2,4 & MEL 2067966 \\
\hline A. ryaniana & Belongs to the $A$. victoriae group. & 2,4 & MEL 721629 \\
\hline A. synchronicia & $\begin{array}{l}\text { In the absence of flowers, } A \text {. victoriae may be confused } \\
\text { with } A \text {. synchronicia. }\end{array}$ & 2,4 & MEL 2252506 \\
\hline A. marramamba & Belongs to the $A$. pyrifolia group. & 2,4 & MEL 2313077 \\
\hline A. strongylophylla & Presence of spinose stipules. & 2,4 & MEL 2287670 \\
\hline
\end{tabular}

${ }^{*}$ Sequences available in GenBank: A. melvillei: FJ868397.1; FJ868438.1; A. victoriae: DQ029275.1, DQ029316.1; A. alexandri: DQ029264.1, DQ029306.1; A. cuspidifolia: DQ029261.1, DQ029302.1; $A$. dempsteri: DQ029259.1, DQ029300.1. References: 1: Maslin (2001); 2: Orchard \& Wilson (2001b); 3: Chapman \& Maslin (1992); 4: Ariati et al. (2006). 


\subsection{Amplification and Sequencing of ITS and ETS Markers}

The ITS region was amplified from the genomic DNAs using the primer pair S3 (5'-AACCTGCGGAAGGATCATTG-3') and 26SE (5'-TAGAATCCCCGGTTCGCTCGCCGT-3') as described previously (Murphy, Miller, Bayer, \& Ladiges, 2003). The ETS region was amplified using the primer pair 18S-IGS (5'-CACATGCATGGCTTAATCTTTG-3') and AcR2 (5'-GGGCGTGTGAGTGGTGTTTGG-3'), as per Murphy, Brown, Miller, and Ladiges (2010) (Figure 1). The $50 \mu \mathrm{L}$ reaction mixes contained $2 \mathrm{mM}$ dNTPs, 25 pmol of each primer, 10-50 ng of DNA template, 1U Taq DNA polymerase and $5 \mu \mathrm{L} 10 \mathrm{X}$ reaction buffer (New England Biolabs, Madison, USA). The PCR products were purified using QIAquick PCR kit (Qiagen) and used for DNA sequencing in both directions for each sample,using the Prism Ready Reaction Dye Deoxy Terminator Cycle Sequencing Kit or Prism Big Dye Terminator Cycle Sequencing Kit (Perkin-Elmer Applied Biosystems, Mulgrave, Australia) and the supplier's protocols.

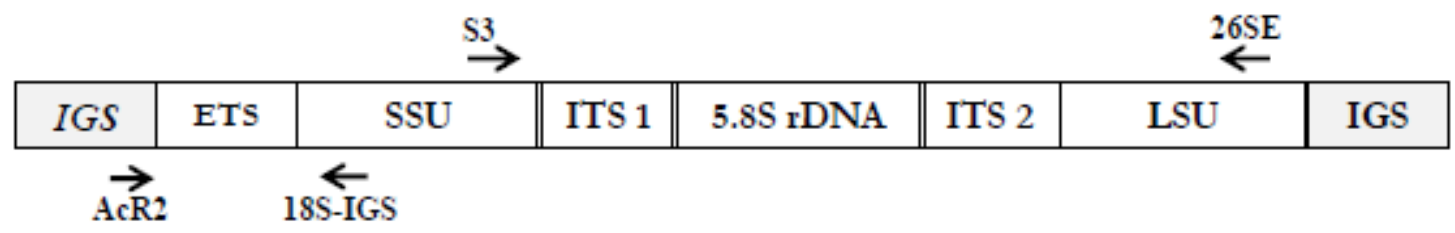

Figure 1. Structure of the ribosomal DNA cistron

S3 denotes the forward primer and 26SE denotes the reverse primer used to amplify the ITS region. AcR2 denotes the forward primer and 18S-IGS denotes the reverse primer used to amplify the ETS region (figure not drawn to scale).

\subsection{Phylogenetic Analysis}

The sequences generated in this study were edited using Sequencher v3.0 (Gene Codes Corporation) and concatenated manually using BioEdit v7.0.0 (Hall, 2007), followed by alignment using ClustalW (http://www.ebi.ac.uk/Tools/msa/clustalw2/). The sequence dataset obtained for 19 species was combined with previous data (Brown et al., 2012) and subjected to Bayesian analysis using MrBayes v3.2.1 (Ronquist \& Huelsenbeck, 2003). For analysis, the combined ITS and ETS data were divided into six partitions: ITS1, 5.8S, ITS2, LSU, SSU and ETS. Insertion/deletion (indel) events were scored as multistate characters. An evolutionary model, GTR (Generalised Time Reversible) substitution model with gamma-distributed rate variation, was applied to each partition. A Markov Chain Monte Carlo (MCMC) search was run for 8 million generations, with trees sampled every 100 generations. Starting from different random trees, the analyses were performed twice simultaneously (Nruns $=2$ ) with four Markov chains $(\mathrm{N}$ chains $=4$ ) for each tree. Burn-in was set to 25001 (i.e. the first 25001 trees were discarded from each run). A Bayesian consensus phylogram was generated and for each node posterior probability (PP) values were calculated. The phylogenetic tree was visualised and coded for display using FigTree (Rambaut \& Drummond, 2008).

\section{Results}

\subsection{Sequence Data}

Of the 30 species of interest sampled based on morphological relatedness, 19 yielded good quality sequence data for both ITS and ETS markers. For five species (A. victoriae, A. alexandri, A. aphanoclada, A. cuspidifolia, A. dempsteri) that did not produce high quality sequences, the ITS and ETS data available in GenBank as part of the dataset of Brown et al. (2012) were used for further analysis. Six species (A. ampliceps, A. bivenosa, A. didyma, A. sclerosperma, A. startii, A. telmica) could not be analysed due to poor amplification results or poor quality sequences, and there were no corresponding sequences in GenBank; hence these were excluded from further analysis. The length of the individual regions, including the aligned versus the unaligned (raw sequence) lengths, for the 24 species is given in Table 2. The partial length of ITS1 (196 base pairs; bp) (Table 2) appears somewhat shorter than previously reported lengths for Acacia ITS1 (Murphy et al., 2003; 2010), due to some unresolved bases occurring close to the primer binding site near the 5' end of the ITS. The sequence data for $5.8 \mathrm{~S}$ subunit and ITS2 region were complete. All $5.8 \mathrm{~S}$ subunit sequences were $159 \mathrm{bp}$ long, as found previously (Murphy et al., 2003; 2010). The ITS2 ranged from 149 bp (A. pickardii) to 215 bp (A.xanthina). The ETS region varied from 393 to $407 \mathrm{bp}$. 
Table 2. Sequence characteristics of ITS1, 5.8S, ITS2 and ETS regions

\begin{tabular}{lllllll}
\hline \multirow{2}{*}{ Sequenced region } & ITS1 & $5.8 \mathrm{~S}$ & ITS2 & LSU & ETS & SSU \\
& $(1-196)$ & $(197-355)$ & $(356-571)$ & $(572-712)$ & $(713-1129)$ & $(1130-1147)$ \\
\hline Aligned length & 196 & 159 & 216 & 141 & 416 & 18 \\
Unaligned length & $108-188$ & 159 & $149-215$ & $0-137$ & $393-407$ & $17-18$
\end{tabular}

Numbers indicate length in bp. The aligned length indicates an overall range of lengths, based on the alignment of all individual raw sequences and including gaps. The unaligned length denotes the lengths of raw sequences from individual species without gaps.

\subsection{Bayesian Analysis of the Combined ITS and ETS Regions Incorporated Into the Larger Dataset}

The sequence data generated for the 24 taxa altogether were incorporated into the larger dataset of Brown et al. (2012) for a total of 178 sequences (including the out-group P. lophantha) and used for Bayesian analysis. The length of the concatenated ITS and ETS sequences was $1290 \mathrm{bp}$. A total of 8 indel characters (6 from ITS and 2 from ETS regions) were scored. The average standard deviation of split frequencies was 0.010 and the average potential scale reduction factor was 1.001. The consistency index was 0.146 and retention index was 0.695 . Incorporation of the new dataset showed that some of the species fall into previously recognised clades (Murphy et al., 2010; Miller et al., 2011; Brown et al., 2012), e.g., the A. aulacocarpa group, A. auriculiformis group, and the A. victoriae and A. pyrifolia group (Figure 2).

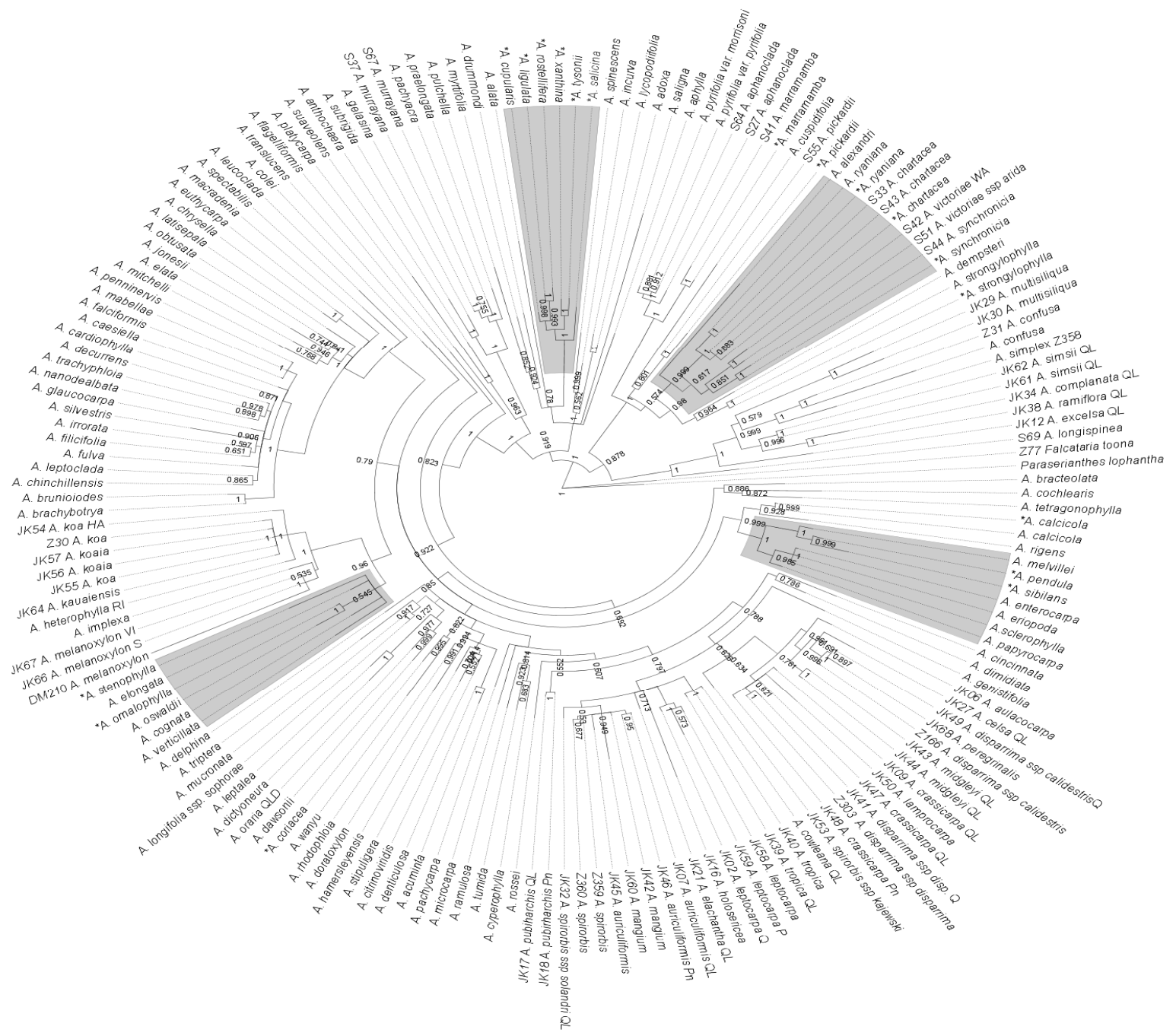

Figure 2. Phylogenetic tree of Acacia species 
The tree is displayed using Fig Tree (Rambaut and Drummond, 2008), with data from Bayesian analysis of 178 Acacia species. The four known salinity-tolerant species of interest (A. victoriae, A. salicina, A. pendula, A. stenophylla) and their closest relatives are shaded in grey.

As seen in Figure 2, A. pendula is sister to A. sibilans, and A. stenophylla falls into a weakly supported ( $\mathrm{PP}=$ 0.545 ) clade comprising A. omalophylla, A. elongata, A. oswaldii, A. cognata and A. verticillata. This observation varies slightly from that based on morphological similarity; $A$. pendula was expected to be more related to A. omalophylla, and in turn to A. melvillei, and A. sibilans is morphologically related to A. stenophylla as per Flora of Australia (Orchard \& Wilson, 2001b). A. pendula sampled in this study is closely related to taxa in two smaller clades (A. papyrocarpa, A. enterocarpa, A. eriopoda and A. sclerophylla, and A. calcicola and A. rigens). This group has narrow, sclerophyllous phyllodes and grows mostly in arid and semi-arid regions (Murphy et al., 2010). The results of the present study suggest that further morphological and molecular sampling of these groups is necessary, as specimens in herbaria may be cryptic and misidentification cannot be ruled out for non-fruiting material.

The A. victoriae group, which is named after the taxon A. victoriae, is closely related to the A. pyrifolia group, and the two groups were informally named as the 'A. victoriae and $A$. pyrifolia clade' by Murphy et al. (2010). In this study, A. victoriae is found to be sister to A. synchronicia, and in turn is placed in a larger clade with $A$. chartacea, A. ryaniana and A. alexandri. This strongly supported clade $(\mathrm{PP}=0.999)$ has been resolved in previous reports (Ariati, Murphy, Udovicic, \& Ladiges, 2006; Murphy et al., 2010; Miller et al., 2011; Brown et al., 2012), but the salinity tolerance of these species has not been assessed.

The fourth grouping resolved $A$. salicina in a strongly supported clade $(\mathrm{PP}=1.0)$ with A. cupularis, A. ligulata, A. rostellifera, A. xanthina and $A$. tysonii, as expected based on their morphological grouping as the ' $A$. bivenosa' group, as per Flora of Australia (Orchard \& Wilson; 2001a; b). However, A. cupularis is sister to A. ligulata and A. rostellifera than to A. xanthina as predicted.

\section{Discussion}

In this paper, the development of new ITS and ETS molecular datasets for 19 taxa of specific interest due to their close relation to four known salt-tolerant species is reported. This is followed by incorporation of these samples into a larger molecular phylogenetic study of Brown et al. (2012). The paper serves as a model for more efficient use of molecular data not only for testing phylogenetic relationships, but also for other application-oriented outcomes.

The four main salt-tolerant species, A. pendula, A. stenophylla, A. salicina and A. victoriae, selected based on the Kamarooka Project (NUFG, Bendigo, Australia; http://www.nufg.org.au/Kamarooka\%20Project.htm) for this work, have other potential applications, but are currently under-utilized. A. pendula is known for its strong and dense wood, and used as an ornamental tree, or for firewood, and for making small wooden articles (Department of Primary Industries, Victoria; http://www.dpi.vic.gov.au/forestry/investment-trade/regional-information/farm-forestry-in-the-north-central-regi on/myall). A. pendula is also a useful stock fodder in drought (World Wide Wattle; http://www.worldwidewattle.com/). Some species related to A. pendula are salt tolerant, e.g., A. calcicola, with a salinity tolerance of $16.5 \mathrm{dS} / \mathrm{m}$ under hydroponic conditions (Malik \& Ahmed, 2002) and $19.9 \mathrm{dS} / \mathrm{m}$ of root zone salinity (Akhter, Ahmed, \& Malik, 2002), while others such as A. papyrocarpa may be suitable for salty land (Government of South Australia, http://www.pir.sa.gov.au/_data/assets/pdf_file/0005/139163/salinity.pdf), but a definitive range of their tolerance is yet to be determined. A. calcicola, with a tolerance range of $16.5-19.9 \mathrm{dS} / \mathrm{m}$, can be classified as highly salt tolerant, with soil electrical conductivity (EC) $>16 \mathrm{dS} / \mathrm{m}$ being considered extremely saline (Food and Agricultural Organisation (FAO) http://www.fao.org/docrep/x5871e/x5871e04.htm). Additionally, A. calcicola can be used for fuel, shade, shelter and windbreaks (FAO; http://ecocrop.fao.org/ecocrop/srv/en/cropView?id=2591). A. enterocarpa, another close relative, is a nationally 'Endangered' species (Moritz \& Bickerton, 2011), and both species have been reported as frost tolerant (Bird, Kearney, \& Jowett, 1996). Thus certain favourable characteristics may be shared within clades identified in phylogenetic studies.

A. stenophylla falls into a weakly supported clade with A. verticillata, A. cognata, A. elongata, A. oswaldii and A. omalophylla (Figure 2), although the relationships within this clade are not fully resolved. A. stenophylla is capable of growth in extremely saline sites (EC $>16 \mathrm{dS} / \mathrm{m})(\mathrm{FAO})$. It is highly frost tolerant (Bird et al., 1996) as well as tolerant to highly alkaline soils and waterlogging (Marcar \& Crawford, 2004). The salinity tolerance of $A$. verticillata, A. elongata, A. oswaldii and A. omalophylla needs to be determined. 
The A. victoriae group is a well-characterised monophyletic clade (Ariati et al., 2006). Maslin (1992) had revised this group and included ten species (nine included in the present analysis) found mainly in arid parts of Australia, i.e., A. victoriae Benth., A. alexandri Maslin, A. aphanoclada Maslin, A. chartacea Maslin, A. cuspidifolia Maslin, A. dempsteri F. Muell., A. glaucocaesia Domin, A. pickardii Tind., A. ryaniana Maslin and A. synchronicia Maslin. Most of these are characterised by spinose stipules, similar phyllode characteristics and a minute gland near the apical mucro (Ariati et al., 2006; Orchard \& Wilson, 2001a; b). A. victoriae was found to be sister to a clade comprising A. synchronicia, and in turn to A. chartacea and A. ryaniana. The relationship of $A$. chartacea and $A$. ryaniana is strongly supported $(\mathrm{PP}=1.0)$. No data exists yet on the salinity tolerance of species closely related to A. victoriae. A. victoriae is of interests also due to its seed pods being a source of Avicins, which have a strong potential as anti-tumor drugs (Lemeshko, Haridas, Quijano-Pérez, \& Gutterman, 2006).

A. salicina also has strong potential in medicinal chemistry, with its leaves having bioactive compounds that have anti-mutagenic, anti-genotoxic and antioxidant potency (Chatti, Boubaker, Skandrani, Bhouri, Ghedira, \& Ghedira, 2011; Boubaker, Mansour, Ghedira, \& L. Ghedira, 2012). A. salicina has been shown to be sister (PP = 1.0) to a clade comprising A. cupularis, A. ligulata, A. rostellifera, A. xanthina and A. tysonii (Figure 2). A.ligulata is described as 'somewhat salt tolerant' based on the salt tolerance of its seedlings (Yokota, 2003). A.ligulata is a prospective candidate for revegetation of areas with slight to moderate salinity, A. xanthina is recorded to grow on arid lands and limestone, while A. tysonii is a species with hard wood, and is advantageous for soil stabilisation in saline sites (World Wide Wattle; http://www.worldwidewattle.com/). Thus a number of species in the A. salicina clade may be suitable for revegetation purposes.

Ascertaining the relationships of the four target species and their closest relatives based on phylogenetics has helped in narrowing the identification process of putative salt tolerant species. This is significant since there is such limited data on salinity tolerance for the vast number ( $>1000)$ of Australian Acacia species, as large scale testing of salinity tolerance parameters is time consuming and prohibitively expensive. As such, a rapid and inexpensive methodology to flag candidate species as described here, is highly significant. The utilisation of DNA markers such as ITS and ETS, is highly informative due to the large amount of already available sequence data. The molecular phylogenetic screening could be followed by testing the select species for physiological markers such as biomass and ion accumulations in laboratory and eventually field conditions. The selected molecular phylogeny approach could be extended to other taxa, or tolerance to other traits such as frost, drought, alkalinity or water logging often associated with salinity tolerance, or phytochemical composition, weediness potential, forage potential, and other characteristics important for utilisation. Thus the results presented here may help in rational selection of candidate plants that not only provide a 'green cover' for the landscape but also contribute to its productivity.

Bui (2013) provide strong evidence that salt stress may have been a crucial element in the adaptation and evolution of Australian vegetation and propose that it may also have been involved in the speciation of acacias. $A$. harpophylla, A. cambagei and A. argyrodendron belong to the same clade and all can grow on alkaline and saline soils; however, not all species related to these can grow on saline lands. Species that grew on saline as well as alkaline soils were found to form distinct groups within the clade (Bui \& Henderson, 2003; Bui, 2013). The reports show that molecular phylogeny can serve as a useful tool for envisaging plant growth characteristics based on edaphic, climatic and biogeographical factors. The method could also provide candidates from unrelated genera, based on species richness of a specific landscape.

\section{Conclusion}

Many Acacia species are capable of withstanding abiotic stress conditions. The preliminary molecular selection process developed here can assist in more rapid selection of native germplasm for field testing, to identify suitable candidates for agroforestry, land reclamation and biodiversity conservation, without the need for transgenic technologies.

\section{Acknowledgements}

This work was supported by the Australian Research Council Linkage Project grant LP0990326. The authors would like to thank the Royal Botanic Gardens Melbourne (MEL herbarium) for providing herbarium samples, Mr Phil Dyson and Mr Ian Rankin (Northern United Forestry Group, Bendigo, Australia) for advice on the four main species used in the project, and Kristy Lam (CSIRO Canberra) for expert support with DNA sequencing. 


\section{References}

Akhter, J., Ahmed, S., \& Malik, K. A. (2002). Use of brackish water for agriculture: growth of salt-tolerant plants and their effects on soil properties. Science Vision, 7, 230-240.

Ariati, S. R., Murphy, D. J., Udovicic, F., \& Ladiges, P. Y. (2006). Molecular phylogeny of three groups of acacias (Acacia subgenus Phyllodineae) in arid Australia based on the internal and external transcribed spacer regions of nrDNA. Systematics and Biodiversity, 4, 417-426. http://dx.doi.org/10.1017/S1477200006001952

Baldwin, B. G., \& Markos, S. (1998). Phylogenetic utility of the External Transcribed Spacer (ETS) of 18S-26S rDNA: Congruence of ETS and ITS Trees of Calycadenia (Compositae). Molecular Phylogenetics and Evolution, 10, 449-463. http://dx.doi.org/10.1006/mpev.1998.0545

Bird, P. R., Kearney, G., \& Jowett, D. (1996). Trees and shrubs for south west Victoria, Department of Agriculture, Pastoral and Veterinary Institute. p. 62.

Boubaker, J., Mansour, H., Ghedira, K., \& Ghedira, L. (2012). Polar extracts from (Tunisian) Acacia salicina Lindl. Study of the antimicrobial and antigenotoxic activities. BMC Complementary and Alternative Medicine, 12, 37. http://dx.doi.org/10.1186/1472-6882-12-37

Brown, G. K., Murphy, D. J., Miller, J. T., \& Ladiges, P. Y. (2008). Acacia s.s. and its relationship among tropical legumes, Tribe Ingeae (Leguminosae: Mimosoideae). Systematic Botany, 33, 739-751. http://dx.doi.org/10.1600/036364408786500136

Brown, G. K., Murphy, D. J., Kidman, J., \& Ladiges, P. Y. (2012). Phylogenetic connections of phyllodinous species of Acacia outside Australia are explained by geological history and human-mediated dispersal. Australian Systematic Botany, 25, 390-403. http://dx.doi.org/10.1071/SB12027

Bui, E. N. (2013). Soil salinity: A neglected factor in plant ecology and biogeography. Journal of Arid Environments, 92, 14-25. http://dx.doi.org/10.1016/j.jaridenv.2012.12.014

Bui, E. N., \& Henderson, B. L. (2003). Vegetation indicators of salinity in northern Queensland. Austral Ecology, 28, 539-552. http://dx.doi.org/10.1046/j.1442-9993.2003.01311.x

Chaer, G. M., Resende, A. S., Campello, E. F. C., De Faria, S. M., \& Boddey, R. M. (2011). Nitrogen-fixing legume tree species for the reclamation of severely degraded lands in Brazil. Tree Physiology, 31, 139-149. http://dx.doi.org/10.1093/treephys/tpq116

Chatti, I. B., Boubaker, J., Skandrani, I., Bhouri, W., Ghedira, K., \& Chekir-Ghedira, L. (2011). Antioxidant and antigenotoxic activities in Acacia salicina extracts and its protective role against DNA strand scission induced by hydroxyl radical. Food and Chemical Toxicology, 49, 1753-1758. http://dx.doi.org/10.1016/j.fct.2011.04.022

Cracraft, J. (2002). The seven great questions of systematic biology: An essential foundation for conservation and the sustainable use of biodiversity. Annals of the Missouri Botanical Garden, 89, 157. http://dx.doi.org/10.2307/3298558

Department of Primary Industries, Victoria; Weeping Myall http://www.dpi.vic.gov.au/forestry/investment-trade/regional-information/farm-forestry-in-the-north-central -region/myall; last accessed July 2013

Department of Sustainability, Environment, Water, Population and Communities, Australian Government; http://www.environment.gov.au/land/pressures/salinity/last visited July 2013

Dong, W., Liu, J., Yu, J., Wang, L., \& Zhou, S. (2012). Highly variable chloroplast markers for evaluating plant phylogeny at low taxonomic levels and for DNA barcoding. PLoS ONE, 7, e35071. http://dx.doi.org/10.1371/journal.pone.0035071

Food and Agricultural Organisation of the United Nations (FAO) Saline soils and their management http://www.fao.org/docrep/x5871e/x5871e04.htm; Acocrop Acacia Amnicola http://ecocrop.fao.org/ecocrop/srv/en/cropView?id=2591;Annex 6. Trees and shrubs for saltland, salinity ratings and species list (http://www.fao.org/docrep/005/y4263e/y4263e0j.htm); (all last accessed July 2013).

Government of South Australia. Woods and Forests. http://www.pir.sa.gov.au/_data/assets/pdf_file/0005/139163/salinity.pdf; last accessed July 2013.

Hall, T. (2007). BioEdit: a user-friendly biological sequence alignment editor and analysis program for Windows 
95/98/NT Nucleic Acids Symposium Series, 41, 95-98.

Hoque, M. S., Broadhurst, L. M., \& Thrall, P. H. (2011). Genetic characterization of root-nodule bacteria associated with Acacia salicina and A. stenophylla (Mimosaceae) across south-eastern Australia. International Journal of Systematic and Evolutionary Microbiology, 61, 299-309. http://dx.doi.org/10.1099/ijs.0.021014-0

Kay, K., Whittall, J., \& Hodges, S. (2006). A survey of nuclear ribosomal internal transcribed spacer substitution rates across angiosperms: an approximate molecular clock with life history effects. BMC Evolutionary Biology, 6, 36.

Lemeshko, V. V., Haridas V., Quijano-Pérez J. C., \& Gutterman J. U. (2006). Avicins, natural anticancer saponins, permeabilize mitochondrial membranes. Archives of Biochemistry and Biophysics, 454, 114-122. http://dx.doi.org/10.1016/j.abb.2006.08.008

Malik, K. A., \& Ahmad, R. (2002). Prospects of saline agriculture in Pakistan: today and tomorrow. In K. A. Malik, \& R. Ahmad (Eds.), Prospects for Saline Agriculture (pp. 1-6), Kluwer Academic Publishers, Netherlands.

Marcar, N., \& Crawford, D. (2004). Trees for saline landscapes. Rural Industries Research and Development Corporation (RIRDC), Canberra, Australia.

Maslin, B. R. (1992). Acacia Miscellany 6: A review of Acacia victoriae and related species (Leguminosae: Mimosoideae: Section Phyllodineae). Nuytsia, 8, 285-309.

Maslin, B. R. (2001). Introduction to Acacia. In A. E. Orchard, \& A. J. G. Wilson (Eds.), Flora of Australia (Volume 11A, pp. 3-13). Melbourne, Australia: ABRS/CSIRO Publishing.

Maslin, B. R. (2006). Generic and infrageneric names in Acacia following retypification of the genus. The Science behind Acacia: Current Research and Recent Discoveries, Melbourne, Australia.

Maslin, B. R., \& McDonald, M. W. (2004). AcaciaSearch- Evaluation of Acacia as a woody crop option for southern Australia, Rural Industries Research and Development Corporation, Canberra, p. 5, Union Offset Printers.

Miller, J. T., Murphy, D. J., Brown, G. K., Richardson, D. M., \& González-Orozco, C. E. (2011). The evolution and phylogenetic placement of invasive Australian Acacia species. Diversity and Distributions, 17, 848-860. http://dx.doi.org/10.1111/j.1472-4642.2011.00780.x

Moritz, K. N., \& Bickerton, D. C. (2011). Recovery plan for the nationally endangered jumping-jack wattle Acacia enterocarpa. Report to the Recovery Planning and Implementation section, Australian Government Department of Sustainability, Environment, Water, Population and Communities, Canberra. Department for Environment and Natural Resources, South Australia.

Mort, M. E., Archibald, J. K., Randle, C. P., Levsen, N. D., O'leary, T. R., Topalov, K., \& Crawford, D. J. (2007) Inferring phylogeny at low taxonomic levels: utility of rapidly evolving cpDNA and nuclear ITS loci. American Journal of Botany, 94, 173-183. http://dx.doi.org/10.3732/ajb.94.2.173

Murphy, D. J. (2008). A review of the classification of Acacia (Leguminosae, Mimosoideae). Muelleria, 26, $10-26$

Murphy, D. J., Brown, G. K., Miller J. T., \& Ladiges, P. Y. (2010). Molecular phylogeny of Acacia Mill. (Mimosoideae: Leguminosae): Evidence for major clades and informal classification. Taxon, 59, 7-19.

Murphy, D. J., Miller, J. T., Bayer, R. J., \& Ladiges, P. Y. (2003). Molecular phylogeny of Acacia subgenus Phyllodineae (Mimosoideae: Leguminosae) based on DNA sequences of the internal transcribed spacer region. Australian Systematic Botany, 16, 19-26. http://dx.doi.org/10.1071/SB01042

Niknam, S. R., \& McComb, J. (2000). Salt tolerance screening of selected Australian woody species - a review. Forest Ecology and Management, 139, 1-19. http://dx.doi.org/10.1016/S0378-1127(99)00334-5

Northern United Forestry Group Kamarooka Project; Retrieved from http://www.nufg.org.au/Kamarooka\%20Project.htm

Orchard, A. E., \& Wilson, A. J. G. (Eds.). (2001a). Flora of Australia. Volume 11A, Mimosaceae, Acacia part 1, ISBN 978064306718 9, Melbourne, Australia, Australian Biological Resources Study and CSIRO Publishing.

Orchard, A. E., \& Wilson, A. J. G. (Eds.). (2001b). Flora of Australia. Volume 11A, Mimosaceae, Acacia part 2, 
ISBN 978064306720 2, Melbourne, Australia, Australian Biological Resources Study and CSIRO Publishing.

Pannell, D. J., \& Roberts, A. M. (2010). Australia's National Action Plan for Salinity and Water Quality: a retrospective assessment. Australian Journal of Agricultural and Resource Economics, 54, 437-456. http://dx.doi.org/10.1111/j.1467-8489.2010.00504.x

Rambaut, A., \& Drummond, A. (2008). FigTree: Tree figure drawing tool, version 1.2. 2. Institute of Evolutionary Biology, University of Edinburgh.

Ronquist, F., \& Huelsenbeck, J. P. (2003). MrBayes 3: Bayesian phylogenetic inference under mixed models. Bioinformatics, 19, 1572-1574. http://dx.doi.org/10.1093/bioinformatics/btg180

Vercoe, T. (1987). Fodder potential of selected Australian tree species. ACIAR Proceedings, Australian Centre for International Agricultural Research, 95-100.

World Wide Wattle. (http://www.worldwidewattle.com/, last accessed July 2013).

Yokota, S. (2003). Relationship between salt tolerance and proline accumulation in Australian acacia species. Journal of Forest Research, 8, 89-93. http://dx.doi.org/10.1007/s103100300010

\section{Copyrights}

Copyright for this article is retained by the author(s), with first publication rights granted to the journal.

This is an open-access article distributed under the terms and conditions of the Creative Commons Attribution license (http://creativecommons.org/licenses/by/3.0/). 